\title{
Ruokohelven käyttökelpoisuus rehukasvina
}

\author{
Mika Isolahti, Päivi Lamminen ja Arto Huuskonen
}

MTT Pohjois-Pohjanmaan tutkimusasema,92400Ruukki,etunimi.sukunimi@mtt.fi

\section{Tiivistelmä}

Ruokohelpi (Phalaris arundinacea L.) on pitkäkasvuinen monivuotinen nurmikasvi, joka on sopeutunut hyvin kosteille maille. Ruokohelven viljely biopolttoaineeksi ja energiantuotantoon on Suomessa voimakkaassa kasvussa, mutta kasvin rehukäyttö on meillä vähäistä. Pohjois-Amerikassa ruokohelpi on kuitenkin yleinen nurmikasvi, ja sitä pidetään tuottoisana etenkin riittävästi typpilannoitusta käytettäessä. Ruokohelven rehukäyttöä on aiemmin haitannut kasvin suuri alkaloidipitoisuus, mutta nykyiset alkujaan rehuntuotantoon jalostetut lajikkeet ovat matala-alkaloidisia. Kaikki Suomessa tällä hetkellä käytettävät lajikkeet ovat pohjoisamerikkalaista alkuperää olevia rehulajikkeita.

MTT:n Pohjois-Pohjanmaan tutkimusasemalla toteutettiin vuosina 2000-2003 koesarja, missä ruokohelpeä (lajike Palaton) verrattiin timoteihin (Phleum pratense L.) (lajike Tuukka), ruokonataan (Festuca arundinaceae) (lajike Retu) ja rehukattaraan (Bromus inermis) (lajike Kesto) ruokohelven rehuntuotantoarvon selvittämiseksi. Erillisessä korjuuaikavertailussa seurattiin ruokohelven sadon ja rehuarvon kehitystä eri niitoissa. Ruokohelpi oli molemmissa kenttäkokeissa kahden ja kolmen niiton järjestelmissä. Jokaisen niiton osalta sadon määrän ja laadun kehitystä seurattiin kahden viikon ajan korjuuaikavertailussa, viidestä näytteenottoajankohdasta keskimmäinen oli samana päivänä kuin kasvilajivertailussa vastaavan ruokohelven niitto. Rehuarvon määrittämiseksi analysoitiin orgaanisen aineen sulavuus (in vitro), typpipitoisuus, tuhka ja NDF-kuitu.

Ruokohelpi tuottaa sopivissa olosuhteissa muita nurmikasveja korkeampia kuiva-ainesatoja. Ensimmäisessä niitossa ruokohelven D-arvo laskee kuitenkin nopeasti. Tavoiteltaessa hyvää rehuarvoa on ruokohelven ensimmäinen sato korjattava aikaisemmin kuin muiden nurmikasvien. Koesarjan perusteella ensimmäisen sadon korjuu on tehtävä viimeistään 45 vuorokauden kuluttua kasvukauden alkamisesta tai kun tehoisan lämpösumman kertymä on 225-230 astetta. Kahden niiton järjestelmää ei ruokohelvelle voi suositella. Kahden niiton järjestelmässä korjuiden väli muodostuu liian pitkäksi ja toisessa sadossa ruokohelven sulavuus ehtii heikentyä liikaa. Kolmen niiton järjestelmässä toisen sadon korjuun optimaalinen korjuuajankohta määrän ja laadun suhteen on tulosten perusteella viisi viikkoa ensimmäisen sadon korjuun jälkeen. Mikäli toinen korjuu tehdään liian aikaisin sadon määrä jää alhaiseksi. Kolmannessa niitossa ruokohelven laadun muutokset ovat vähäisiä ja niiton ajankohtaa voikin siirtää myöhemmäksi, jolloin myös sadon määrä on suurempi. Viimeisen niiton jälkeen ruokohelpi tarvitsee vähintään neljän viikon pituisen jakson karaistumista varten ennen kasvukauden loppua.

Ruokohelpeä ei voida tulosten perusteella suositella ensisijaiseksi vaihtoehdoksi korkeatuottoisille lypsylehmille. Ruokohelpisäilörehu sopii hyvin esimerkiksi emolehmien talvikauden ruokintaan, koska emolehmien ruokinnassa rehunsulavuuden ei tarvitse olla yhtä korkea kuin lypsylehmillä tai loppukasvatettavilla sonneilla.

asiasanat: ruokohelpi, timotei, ruokonata, rehukattara, kuiva-ainesato, rehuarvo, D-arvo, NDF 


\section{Johdanto}

Ruokohelpi (Phalaris arundinacea L.) on pitkäkasvuinen monivuotinen nurmikasvi, joka kasvaa villinä yleisesti koko Suomessa. Ruokohelven viljelyä ja käyttöä biopolttoaineena on selvitetty Suomessa ja muualla Euroopassa laajoissa tutkimus- ja kehityshankkeissa 1990-luvulla (Pahkala ym. 1994, Pahkala ym. 1996, Salo 2000, Pahkala ym. 2005, Powlson ym. 2005). Ruokohelven viljely laajemmassa mitassa biopolttoaineeksi alkoi kuluvan vuosikymmenen alkupuolella päästökaupan käynnistymisen varmistuessa ja ruokohelven viljelyala Suomessa on voimakkaassa kasvussa. Viljelyala energiantuotantoon vuonna 2005 on MMM:n tilastoinnin mukaan Suomessa 10500 hehtaaria.

Ruokohelven rehukäyttö Suomessa on vähäistä. Rehun alkaloidipitoisuuden ja huonon sulavuuden vuoksi ruokohelven lajikejalostuksesta luovuttiin Suomessa 1970-luvulla. Jalostustyön tuloksena syntyi kuitenkin yksi kotimainen rehukäyttöön tarkoitettu linja, Jo 0510 (Ravantti 1980). PohjoisAmerikassa ruokohelpi on yleinen nurmikasvi ja sitä pidetään tuottoisana etenkin riittävää typpilannoitusta käytettäessä (Miller 1984). Ruokohelven rehukäyttöä on aiemmin haitannut kasvin suuri alkaloidipitoisuus, mutta nykyiset alkujaan rehuntuotantoon jalostetut lajikkeet ovat matala-alkaloidisia. Kaikki viljelyssä tällä hetkellä käytettävät lajikkeet ovat Pohjois-Amerikkalaista alkuperää olevia rehulajikkeita.

Alkaloidit ovat orgaanisia typpiyhdisteitä joita syntyy kasvien metabolian sivutuotteena (Pelletier 1970). Alkaloidit toimivat proteiinisynteesin varastona ja lisäksi suojaavat kasveja laiduntavilta eläimiltä ja hyönteisiltä (Pelletier 1970). Rehukasveissa alkaloidit ovat haitallisia, koska ne alentavat rehun maittavuutta ja voivat aiheuttaa eläimille ripulia. Ruokohelveltä on löydetty ainakin yhdeksän eri tyyppistä alkaloidia (Østrem 1987). Gramiinit ovat kaikkein yleisimpiä alkaloideja (Østrem 1987) ja ne alentavat rehun maittavuutta. DMT:llä eli N,N-dimethyltryptamiinilla on todettu myös huumaava vaikutus, mutta Pohjois-Amerikkalaista alkuperää olevissa lajikkeissa sitä ei ole lainkaan (Østrem 1987).

Ruokohelven alkaloidipitoisuuden on havaittu lisääntyvän kuivuudesta aiheutuvan stressin (Marten 1973), matalan valointensiteetin ja korkean typpilannoituksen vaikutuksesta, etenkin käytettäessä ammoniumtyppeä (Frelich ja Marten 1972). Lyhyt niittoväli, noin pari viikkoa, lisää myös selvästi alkaloidien määrää (Woods ja Clark 1971). Ruokohelvessä alkaloidien määrän on havaittu laskevan selvästi kun korjuu tehdään kuivaksi heinäksi (Donker ym. 1976) tai säilörehuksi (Hovin ym. 1980). Tehtäessä ruokohelvestä säilörehua, alkaloideja poistuu puristenesteen mukana (Hovin ym. 1980).

Ruokohelven sadontuottokyky on pohjoisamerikkalaisissa tutkimuksissa ollut selvästi korkeampi kuin muilla nurmikasveilla (Marten ja Hovin 1980, Sheaffer ym. 1990). Ruokohelpi on pitkäikäinen nurmikasvi, joissain tutkimuksissa sen on todettu olevan kestävin nurmikasvi korjuukertojen lukumäärästä huolimatta (Marten ja Hovin 1980).

Amerikkalaisten tutkimusten mukaan ruokohelven oikea korjuuaika on ennen röyhylle tuloa. Tällöin ruokohelven sulavuus on vielä riittävän korkea märehtijöiden ruokintaan. (Sheaffer ym. 1990). Kevätkorjuun jälkeen ruokohelpi ei muodosta enää röyhyä vaikka korjuu olisi tehty ennen kevätsadon röyhylle tuloa. Maksimaaliseen satoon pyrittäessä korjuu on tehtävä, kun ruokohelpi tulee röyhylle. Ruokinnallinen laatu laskee ruokohelvellä nopeasti kun kasvusto ikääntyy. Selityksenä tähän on ligniinin ja muiden kuitumaisten osien sekä soluseinämäkomponenttien lisääntyminen korressa ja lehtien osuuden väheneminen (Marum ja Hovin 1979, Sheaffer ym. 1990).

Ruokohelven etuja rehukasvina on korkea sato ja pitkäikäinen kasvusto. Nykyisillä lajikkeilla korkea alkaloidipitoisuus ei estä ruokohelven käyttöä rehuksi. Sen sijaan liian myöhäinen korjuuaika alentaa rehun laatua, joten korjuuaikojen tarkentaminen on oleellista rehun laadun takaamiseksi.

\section{Aineisto ja menetelmät}

MTT:n Pohjois-Pohjanmaan tutkimusasemalla toteutettiin vuosina 2000-2003 koesarja, missä ruokohelpeä (lajike Palaton) verrattiin timoteihin (Phleum pratense L.) (lajike Tuukka), ruokonataan (Festuca arundinaceae) (lajike Retu) ja rehukattaraan (Bromus inermis) (lajike Kesto) ruokohelven rehuntuotantoarvon selvittämiseksi. Erillisessä korjuuaikavertailussa seurattiin ruokohelven sadon ja rehuarvon kehitystä eri niitoissa. Ruokohelpi oli molemmissa kenttäkokeissa kahden ja kolmen niiton järjestelmissä. Jokaisen niiton osalta sadon määrän ja laadun kehitystä seurattiin kahden viikon ajan korjuuaikavertailussa, viidestä näytteenottoajankohdasta keskimmäinen oli samana päivänä kuin kasvilajivertailussa vastaavan ruokohelven niitto. Rehuarvon määrittämiseksi analysoitiin orgaanisen aineen 
sulavuus (in vitro), typpipitoisuus, tuhka ja NDF-kuitu. Kasvukausien säätiedot on ilmoitettu taulukossa 1.

Taulukko 1. Keskilämpötila ja sademäärä kuukausittain toukokuusta syyskuuhun kasvukauden tehoisan lämpötilan summa vuosina 2000 - 2003, sekä pitkäaikaiset keskiarvot Ruukissa.

\begin{tabular}{|c|c|c|c|c|c|c|c|c|c|c|}
\hline Kuukausi & $\begin{array}{l}2000 \\
\text { keskil }\end{array}$ & 2001 & $\begin{array}{l}2002 \\
{ }^{\circ}{ }^{\circ} \mathrm{C}\end{array}$ & 2003 & $\begin{array}{l}1961- \\
1990\end{array}$ & $\begin{array}{l}2000 \\
\text { sadem }\end{array}$ & $\begin{array}{l}2001 \\
\text { ärä, n }\end{array}$ & 2002 & 2003 & $\begin{array}{l}1961- \\
990\end{array}$ \\
\hline toukokuu & 8,9 & 6,5 & 9,3 & 8,3 & 7,7 & 24 & 39 & 28 & 83 & 36 \\
\hline kesäkuu & 13,1 & 14,1 & 15,0 & 12,4 & 13,2 & 112 & 94 & 31 & 7 & 49 \\
\hline heinäkuu & 16,3 & 16,5 & 17,5 & 19,3 & 15,4 & 48 & 103 & 92 & 83 & 61 \\
\hline elokuu & 13,1 & 13,4 & 15,8 & 13,9 & 13,1 & 97 & 69 & 51 & 34 & 71 \\
\hline syyskuu & 8,2 & 9,0 & 7,8 & 9,0 & 8,0 & 29 & 64 & 59 & 30 & 57 \\
\hline keskimäärin (touko - syys) & 11,9 & 11,9 & 13,1 & 12,6 & 11,5 & 62 & 74 & 52 & 47 & 55 \\
\hline tehoisan lämpötilan summa $\left(>5^{\circ} \mathrm{C}\right)$ & 1245 & 1227 & 1357 & 1240 & 1042 & & & & & \\
\hline
\end{tabular}

Kasvustot perustettiin kesällä 2000 ilman suojakasvia. Koelohkon maalaji oli multava karkea hieta (mKHt). Ennen kokeiden perustamista vanha kasvusto oli hävitetty glyfosaattivalmisteella. Lannoitus tehtiin ympäristötuen tarkennettujen tasojen mukaan viljavuusanalyysin tietojen perusteella. Typpeä käytettiin satovuosina kahden niiton järjestelmässä $100+100 \mathrm{~kg} \mathrm{ha}^{-1}$ ja kolmen niiton järjestelmässä $100+100+50 \mathrm{~kg} \mathrm{ha}^{-1}$.

Aineistojen tilastollinen testaus tehtiin SAS 8.12 -ohjelmistolla. Tulokset analysoitiin varianssianalyysillä käyttäen MIXED-proseduuria. Kenttäkokeet toteutettiin lohkoittain satunnaistettuina eli tilastollinen rakennemalli havainnolle oli $\chi_{i j}=\mu^{+} \alpha_{i}+\beta_{j}+\varepsilon_{i j}$ ja yhdistetylle havainnolle yli koevuosien $\chi_{i j k}=\mu+\alpha_{i}\left(\gamma_{k}\right)+\beta_{j}+\gamma_{k}+\beta_{j}^{*} \gamma_{k}+\varepsilon_{i j k}$. Koekäsittelyjen parivertailut tehtiin Tukeyn testillä.

\section{Tulokset ja tulosten tarkastelu}

Kahden niiton järjestelmässä ruokohelven tuottama kuiva-ainesadon määrä oli selvästi suurempi kuin muiden vertailussa olleiden nurmikasvien (taulukot 3, 4 ja 5). Kolmen niiton järjestelmässä ruokohelven toisen ja kolmannen sadon määrä jäi alhaiseksi ja kokonaissadon määrä oli alempi kuin muilla nurmikasveilla. Ruokohelven kuiva-ainesadon määrä aleni myös ensimmäisessä sadossa kolmen niiton järjestelmässä verrattuna kahden niiton järjestelmään koesarjan aikana (taulukko 3).

Taulukko 2. Ruokohelven D-arvon muutos laskettuna lämpösumman (TLS) ja kasvuajan (VRK) mukaan eri korjuukerroilla ja eri korjuujärjestelmissä Ruukissa vuosina 2001-2003.

\begin{tabular}{|c|c|c|c|c|c|}
\hline \multirow[b]{2}{*}{ Korjuukerta } & \multirow[b]{2}{*}{ Yhtälö } & \multicolumn{2}{|l|}{ vakio } & kulmakerroin & \multirow{2}{*}{$\begin{array}{l}\text { mallin } \\
\text { selitysaste }\end{array}$} \\
\hline & & p-arvo & SEM & p-arvo & \\
\hline 1. sato & $\mathrm{D}$-arvo $=870,71-0,9710 \times \mathrm{TLS}($ kasvukauden alusta $)$ & $* * *$ & 12,170 & $* * *$ & $0,0323 * * *$ \\
\hline 2. sato, (3 korj.) & $\mathrm{D}$-arvo $=759,55-0,4393 \times$ TLS(edellisestä niitosta) & $* * *$ & 9,174 & $* * *$ & $0,0151 * *$ \\
\hline 1. sato & $\mathrm{D}$-arvo $=1056,49-8,8312 \times \mathrm{VRK}_{\text {(kasvukauden alusta) }}$ & $* * *$ & 42,724 & $* * *$ & $0,5989 * * *$ \\
\hline 2. sato, (2 korj.) & D-arvo=486,57 + 0,3272 x VRK(edellisestä niitosta) & $* * *$ & 31,415 & & 0,4370 \\
\hline 2. sato, (3 korj.) & D-arvo=797,75 - 6,1120 x VRK(edellisestä niitosta) & $* * *$ & 12,545 & $* * *$ & $0,3328 * * *$ \\
\hline 3. sato, (3 korj.) & D-arvo=794,79 - 5,2751 x VRK(edellisestä niitosta) & $* * *$ & 25,444 & *** & $0,6531 *$ \\
\hline
\end{tabular}

Vakion ja kulmakertoimen $\mathrm{p}$-arvot $(\mathrm{p}<0,05=*, \mathrm{p}<0,01=* *, \mathrm{p}<0,001=* * *)$ ja keskiarvon keskivirhe (SEM) sekä koko mallin selitysaste ilmoitettu.

Ruokohelven kokonaissatomäärä lisääntyi kasvuston ikääntyessä sekä kahden, että kolmen niiton järjestelmissä koko kolmivuotisen koesarjan ajan, missä suhteessa ruokohelpi poikkesi muista vertailussa olleista nurmikasvilajeista (taulukko 3). Timoteillä ja rehukattaralla kokonaissato pysyi kaikkina vuosina samalla tasolla (taulukko 3). Ruokonadan kuiva-ainesadon määrä aleni toisena kasvukautena ensimmäisessä sadossa talvituhojen takia (taulukko 3), muilla kasveilla ei talvituhoja ollut. Ruokohelven kevättiheys oli silmävaraisessa arvioinnissa alhaisempi kuin muilla nurmikasveilla (tuloksia ei esitet- 
ty). Ruokohelven syystiheyksien (tuloksia ei esitetty) ja satomäärien perusteella ruokohelpi ei kuitenkaan kärsinyt merkittävästi talvituhoista. Selityksenä on ruokohelven alhaisempi versoluku muihin nurmikasveihin, kuten timoteihin verrattuna, mikä on todettu aikaisemmissa tutkimuksissa (Pahkala ym. 1996).

Taulukko 3. Eri nurmikasvien kuiva-ainesadot Ruukissa vuosittain 2001-2003.

2001

\begin{tabular}{|c|c|c|c|c|c|c|c|}
\hline Koejäsen & 1. sato, $\mathrm{kg} \mathrm{ha}^{-1}$ & & 2. sato, $\mathrm{kg} \mathrm{ha}^{-1}$ & & 3. sato, $\mathrm{kg} \mathrm{ha}^{-1}$ & $\begin{array}{c}\text { Kokonaissato, } \\
\mathrm{kg} \mathrm{ha}^{-1} \\
\end{array}$ & \\
\hline Timotei & 4307 & $\mathrm{a}$ & 5347 & $\mathrm{~b}$ & & 9654 & $\mathrm{a}$ \\
\hline Ruokonata & 3309 & $\mathrm{~b}$ & 7187 & $\mathrm{a}$ & & 10495 & $\mathrm{a}$ \\
\hline Rehukattara & 4888 & $\mathrm{a}$ & 5638 & $\mathrm{~b}$ & & 10525 & $\mathrm{a}$ \\
\hline Ruokohelpi, 2 niittoa & 2897 & c & 6676 & $\mathrm{a}$ & & 9573 & $\mathrm{a}$ \\
\hline Ruokohelpi, 3 niittoa & 2732 & $\mathrm{C}$ & 1881 & $\mathrm{c}$ & 925 & 5538 & $\mathrm{~b}$ \\
\hline keskimäärin & 3627 & & 5346 & & & 9157 & \\
\hline P-arvo & $* * *$ & & $* * *$ & & & $* * *$ & \\
\hline SEM & 207,9 & & 205,6 & & & 342,8 & \\
\hline \multicolumn{8}{|l|}{2002} \\
\hline Timotei & 4062 & $\mathrm{ab}$ & 4648 & $\mathrm{~b}$ & & 8710 & $\mathrm{~b}$ \\
\hline Ruokonata & 2326 & $\mathrm{~b}$ & 4950 & $\mathrm{~b}$ & & 7275 & bc \\
\hline Rehukattara & 4518 & $\mathrm{a}$ & 4943 & $\mathrm{~b}$ & & 9461 & $\mathrm{ab}$ \\
\hline Ruokohelpi, 2 niittoa & 3740 & $\mathrm{ab}$ & 7783 & $\mathrm{a}$ & & 11523 & $\mathrm{a}$ \\
\hline Ruokohelpi, 3 niittoa & 3016 & $\mathrm{ab}$ & 2185 & c & 664 & 5865 & $\mathrm{C}$ \\
\hline keskimäärin & 3532 & & 4902 & & & 8567 & \\
\hline P-arvo & $*$ & & $* * *$ & & & $* * *$ & \\
\hline SEM & 429,9 & & 314,4 & & & 642,0 & \\
\hline \multicolumn{8}{|l|}{2003} \\
\hline Timotei & 3759 & $\mathrm{~b}$ & 5782 & $\mathrm{~b}$ & & 9540 & c \\
\hline Ruokonata & 2874 & c & 6790 & $\mathrm{~b}$ & & 9664 & c \\
\hline Rehukattara & 5097 & $\mathrm{a}$ & 5904 & $\mathrm{~b}$ & & 11002 & $\mathrm{~b}$ \\
\hline Ruokohelpi, 2 niittoa & 3887 & $\mathrm{~b}$ & 8491 & $\mathrm{a}$ & & 12378 & $\mathrm{a}$ \\
\hline Ruokohelpi, 3 niittoa & 3466 & $\mathrm{C}$ & 2843 & c & 1600 & 6908 & $\mathrm{~d}$ \\
\hline keskimäärin & 3817 & & 5962 & & & 9898 & \\
\hline P-arvo & $* * *$ & & $* * *$ & & & $* * *$ & \\
\hline SEM & 239,4 & & 248,9 & & & 274,6 & \\
\hline
\end{tabular}

Koekäsittelyiden tilastollinen merkitsevyys: $*=p<0,05, * *=p<0,01, * * *=p<0,001$. Tasokeskiarvot, joiden indeksissä ei ole yhteistä kirjainta, eroavat parittaisen vertailun mukaan merkitsevästi $5 \%$ riskitasolla. Keskiarvon keskivirhe (SEM) on ilmoitettu eri käsittelyille.

Korkeimmat sadot ensimmäisessä niitossa olivat rehukattaralla ja timoteilla (taulukot 3 ja 4). Ruokohelven ja -nadan sadot olivat matalampia hitaamman alkukehityksen vuoksi. Ruokonadan kuivaainesato oli toisessa niitossa selvästi korkeampi kuin timotein ja rehukattaran (taulukot 3 ja 4), syynä eroon on ruokonadan parempi jälkikasvukyky. Ruokonadan ja timotein D-arvot ensimmäisessä niitossa olivat ruokohelpeä ja rehukattaraa korkeampia jokaisena koevuotena (taulukko 4).

Korjuuaikavertailussa ruokohelven ensimmäisen sadon D-arvo aleni lineaarisesti lämpösumman lisääntyessä (taulukko 2 ja kuva 1A). Myös aika kasvukauden alusta selitti hyvin D-arvon muutosta (taulukko 2). D-arvon lasku ruokohelven ensimmäisessä sadossa oli nopeampaa kuin esimerkiksi timoteilla on todettu (Rinne ym. 2002). NDF:n pitoisuudet olivat nurminadalla matalimmat ja ruokohelvellä sekä rehukattaralla korkeimmat ensimmäisessä niitossa (taulukko 4). Ruokohelven ja -nadan raakavalkuaispitoisuus ensimmäisessä niitossa oli selvästi korkeampi kuin timotein tai rehukattaran (taulukko 4). Korjuuaikavertailussa ruokohelven NDF-pitoisuus lisääntyi kasvuston vanhentuessa ja vastaavasti raakavalkuaispitoisuus laski selvästi (kuva 1). 
Taulukko 4. Eri nurmikasvien kuiva-ainesato, sadon laatu ja rehuyksikkösato eri niitoissa keskimäärin Ruukissa vuosina 2001-2003. Tilastollisen testauksen selitykset ilmoitettu taulukossa 3.

1. sato

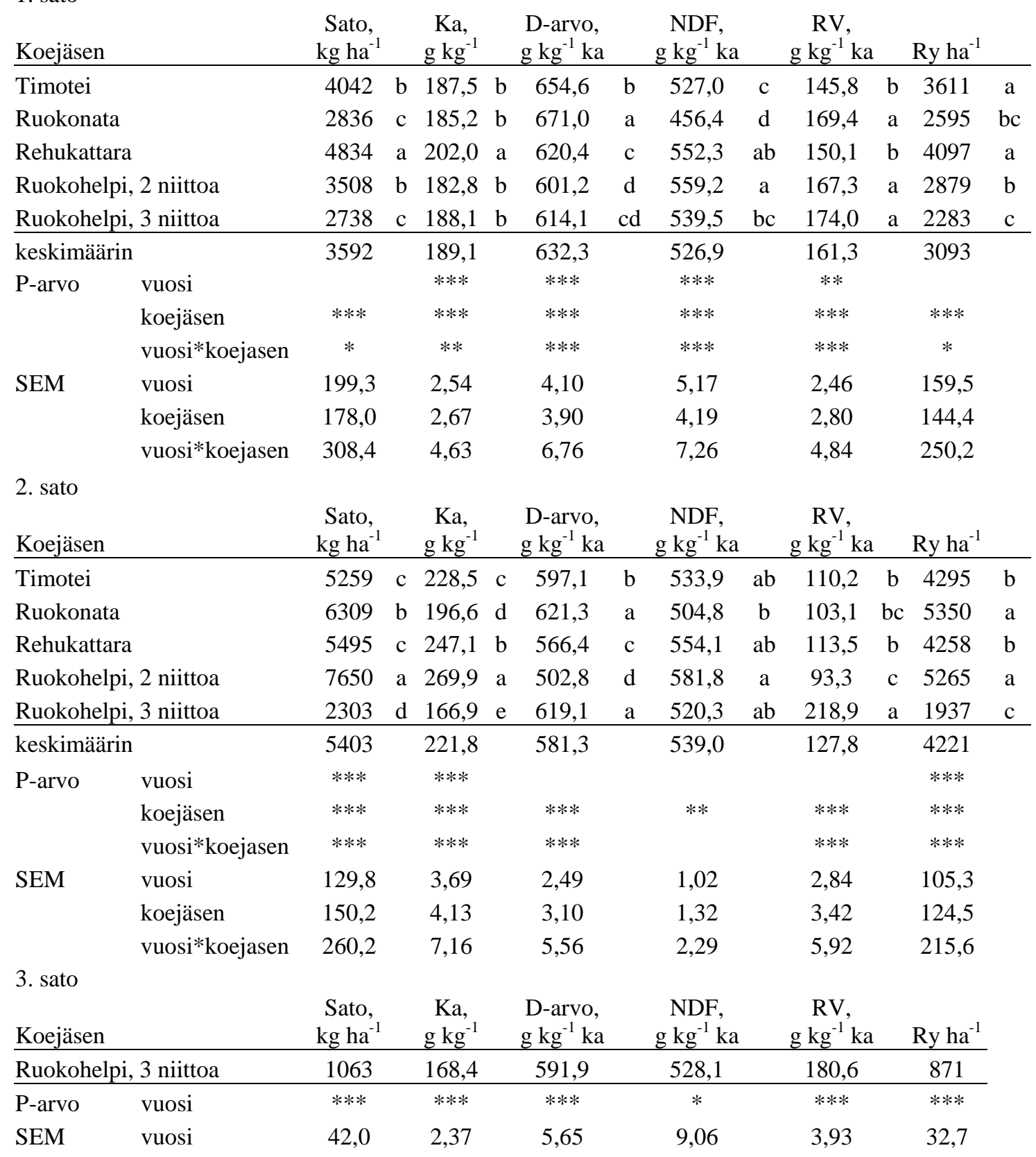

Toisessa niitossa kaikkien kasvilajien D-arvot olivat selvästi ensimmäistä niittoa alempia. Korkeimmat D-arvot toisessa niitossa olivat ruokonadalla ja ruokohelvellä kolmen niiton järjestelmässä. Niiton jälkeen kertynyt lämpösumma selitti ruokohelven D-arvon laskun erittäin hyvin toisessa korjuussa kolmen niiton järjestelmässä (taulukko 2). Kahden niiton järjestelmässä olleen ruokohelven D-arvo oli kaikkein heikoin (taulukko 4). Ruokonadan NDF:n määrä oli alhaisin toisessa niitossa. Kahden niiton järjestelmässä olleen ruokohelven ja rehukattaran NDF:n pitoisuudet olivat selvästi korkeampia kuin muilla nurmikasveilla. Korjuuaikakokeessa ruokohelven NDF-pitoisuus ei toisessa sadossa noussut kasvuston ikääntyessä (kuva 1B), kun ruokohelpeä viljeltiin kahden niiton järjestelmässä. Syynä oli kasvuston vanhentuminen jo ennen toisen sadon korjuuseurannan aloittamista. Ruokohelven kuitupitoisuuden nousu pysähtyy kasvuston ikääntyessä, vastaava on todettu myös raakakuidun osalta (Pahkala ym. 1994). Ruokohelven raakavalkuaispitoisuus kuitenkin laski kasvuston ikääntyessä (kuva 1), mikä vastaa aikaisempia havaintoja (Pahkala ym. 1994). Lämpösumman kertymä edellisen niiton jäl- 
keen ei enää selittänyt ruokohelven D-arvon muutoksia viimeisessä niitossa kummassakaan korjuujärjestelmässä. Tämä vastaa muilla nurmikasveilla tehtyjä havaintoja (Rinne ym. 2002).

Taulukko 5. Eri nurmikasvien kuiva-ainesato rehuyksikkösato keskimäärin Ruukissa vuosina 2001-2003. Tilastollisen testauksen selitykset ilmoitettu taulukossa 3.

\begin{tabular}{|c|c|c|c|c|c|}
\hline Koejäsє & & Sato, $\mathrm{kg} \mathrm{ha}^{-1}$ & & Ry ha ${ }^{-1}$ & \\
\hline Timotei & & 9301 & $\mathrm{~b}$ & 7906 & a \\
\hline Ruokon & & 9145 & $\mathrm{~b}$ & 7945 & $\mathrm{a}$ \\
\hline Rehuka & & 10329 & $\mathrm{a}$ & 8355 & $\mathrm{a}$ \\
\hline Ruokoh & , 2 niittoa & 11158 & $\mathrm{a}$ & 8145 & $\mathrm{a}$ \\
\hline Ruokoh & , 3 niittoa & 6104 & c & 5091 & b \\
\hline keskim & & 9207 & & 7488 & \\
\hline P-arvo & vuosi & * & & $* *$ & \\
\hline & koejäsen & $* * *$ & & $* * *$ & \\
\hline & vuosi*koejäsen & $* * *$ & & $* * *$ & \\
\hline SEM & vuosi & 251,8 & & 193,2 & \\
\hline & koejäsen & 259,3 & & 211,4 & \\
\hline & vuosi*koejäsen & 449,1 & & 366,2 & \\
\hline
\end{tabular}

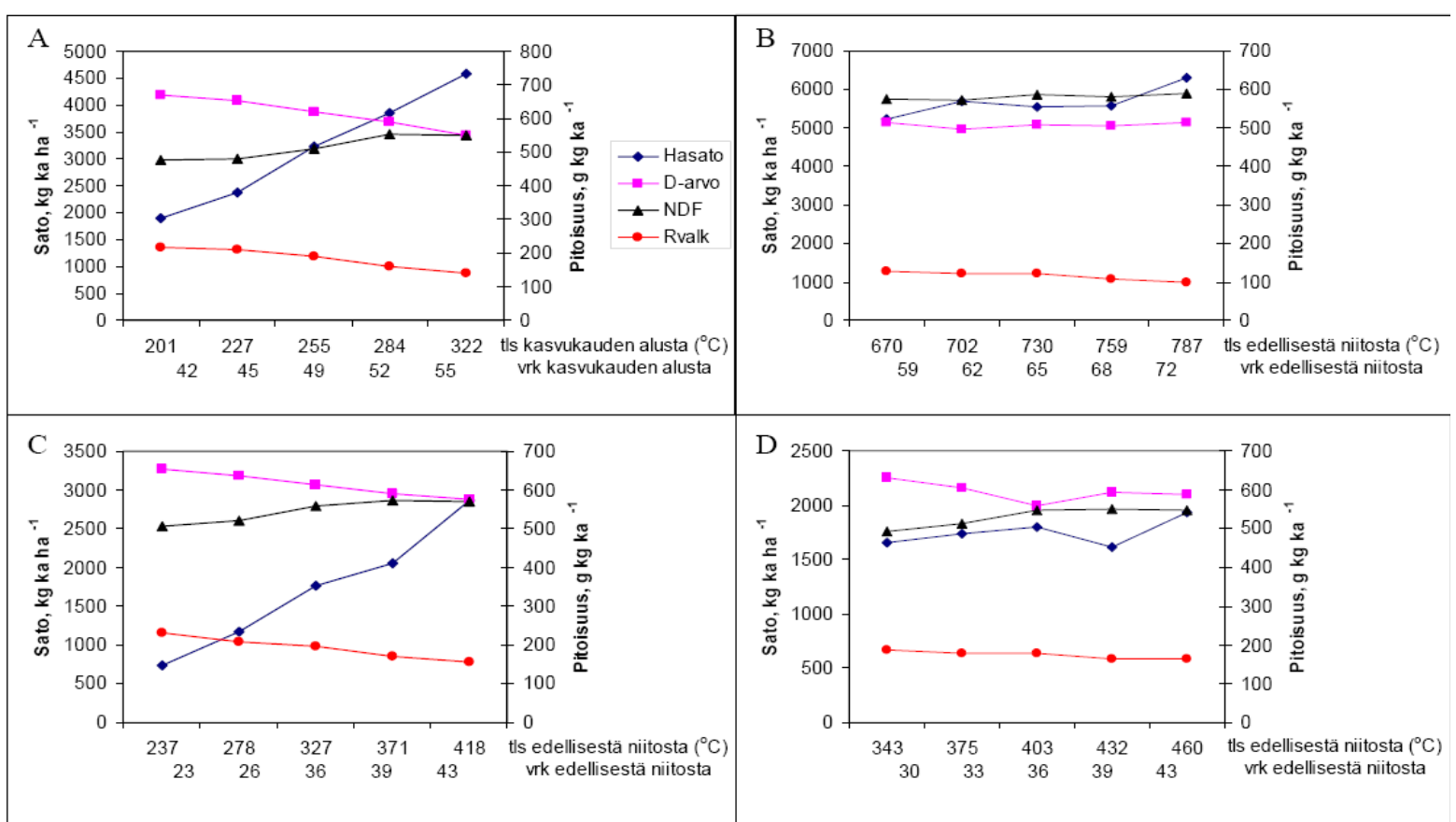

Kuva 1. Ruokohelven kuiva-ainesadon määrän, D-arvon, NDF- ja raakavalkuaispitoisuuden muutos ensimmäisessä sadossa (A), kahden niiton korjuujärjestelmän toisessa sadossa (B), kolmen niiton korjuujärjestelmän toisessa (C) ja kolmannessa sadossa (D) lämpösumman ja ajansuhteen Ruukissa vuosina 2001-2003.

Kolmen niiton järjestelmässä ruokohelven D-arvon muutos pystyttiin selittämään edellisestä korjuusta kuluneella ajalla (taulukko 2), mikä myös vastaa muilla nurmikasveilla tehtyjä havaintoja (Rinne ym. 2002). D-arvon aleneminen ruokohelven jälkikasvussa myöhemmissä niitoissa oli hieman hitaampaa kuin ensimmäisessä sadossa (taulukko 2 ja kuvat 1B ja 1C).

\section{Johtopäätökset}

Ruokohelpi tuottaa sopivissa olosuhteissa muita nurmikasveja korkeampia kuiva-ainesatoja. Ensimmäisessä niitossa ruokohelven D-arvo laskee kuitenkin nopeasti. Tavoiteltaessa hyvää rehuarvoa on ruokohelven ensimmäinen sato korjattava aikaisemmin kuin muiden nurmikasvien. Koesarjan perusteella ensimmäisen sadon korjuu on tehtävä viimeistään 45 vuorokauden kuluttua kasvukauden alkamisesta tai kun tehoisan lämpösumman kertymä on 225-230 astetta. Kahden niiton järjestelmää ei 
ruokohelvelle voi suositella. Kahden niiton järjestelmässä korjuiden väli muodostuu liian pitkäksi ja toisessa sadossa ruokohelven sulavuus ehtii heikentyä liikaa. Kolmen niiton järjestelmässä toisen sadon korjuun optimaalinen korjuuajankohta määrän ja laadun suhteen on tulosten perusteella viisi viikkoa ensimmäisen sadon korjuun jälkeen. Mikäli toinen korjuu tehdään liian aikaisin sadon määrä jää alhaiseksi. Kolmannessa niitossa ruokohelven laadun muutokset ovat vähäisiä ja niiton ajankohtaa voikin siirtää myöhemmäksi, jolloin myös sadon määrä on suurempi. Viimeisen niiton jälkeen ruokohelpi tarvitsee vähintään neljän viikon pituisen jakson karaistumista varten ennen kasvukauden loppua.

Ruokohelpeä ei voida tulosten perusteella suositella ensisijaiseksi vaihtoehdoksi korkeatuottoisille lypsylehmille. Ruokohelpisäilörehu sopii hyvin esimerkiksi emolehmien talvikauden ruokintaan, koska emolehmien ruokinnassa rehunsulavuuden ei tarvitse olla yhtä korkea kuin lypsylehmillä tai loppukasvatettavilla sonneilla.

\section{Kirjallisuus}

Donker, J. D., Bhargava, P. K., Jordan, R. M., Marten G. C. 1976. Effects of drying on forage quality of alfaalfa and reed canarygrass fed to lambs. Can. J. Plant Sci. 56:837-845.

Frelich, J. R. \& Marten, G. C. 1972. Factors influencing indole alkaloids in reed canarygrass, Phalaris arundinacea L. Agron. Abstr. s. 68.

Hovin, A. W., Solber, Y., Myhr, K. 1980. Alkaloids in Reed canary grass Grown in Norway and the USA. Acta Agric. Scan. 30:211-215.

Marten, G. C. 1973. Alkaloids in reed canarygrass. In: A. G. Matches (eds.). Antiquality components of forages. Special Publish 4 Crop Science Society America. Madison, Wisconsin, USA. 15-31.

Marten G. C. \& Hovin, A. W. 1980. Harvest schedule, persistence, yield and quality interactions among four perennial grasses. Agronomy Journal. 72:378-387.

Marum, P. \& Hovin A. W. 1979. Cell wall constituents in plant parts of reedcanary clones. Crop Sci. 19:280284.

Miller, D. A. 1984. Forage Crops. McGraw-Hill book company. 530 s.

Pahkala, K., Mela, T. \& Laamanen, L. 1994. Agrokuidun tuotanto- ja käyttömahdollisuudet Suomessa. Alustavan tutkimuksen loppuraportti 1990-1992. Maatalouden tutkimuskeskus. Tiedote 12/94. Jokioinen: Maatalouden tutkimuskeskus. 55 p.

Pahkala, K., Mela, T., Hakkola, H., Järvi, A., Virkajärvi, P. 1996. Agrokuidun tuotanto ja käyttö Suomessa. Tutkimuksen loppuraportti, I osa. Agrokuitukasvien viljely. Viljelytoimenpiteiden ja lajikevalinnan vaikutus agrokuitukasvien satoon ja kivennäiskoostumukseen. Maatalouden tutkimuskeskus, sarja A 3: 68 s. + liitt. $15 \mathrm{~s}$.

Pahkala, K., Isolahti, M., Partala, A., Suokannas, A., Kirkkari, A-M., Peltonen, M., Sahramaa, M., Lindh, T., Paappanen, T., Kallio, E., Flyktman, M. 2005. Ruokohelven viljely ja korjuu energian tuotantoa varten. 2. korjattu painos. Maa- ja elintarviketalous 1: $31 \mathrm{~s}$.

Pelletier, S. W. 1970 The plant alkaloids - general information. -In: Chemistry of the Alkaloids. Van Norstrand Reinholdt Co., New York. 1-10.

Powlson, D. S., Riche, A. B., Shield, I. 2005. Biofuels and other approaches for decreasing fossil fuel emissions from agriculture. Ann. Appl. Biol. 146 (2):193-201.

Østrem, L. 1987. Studies on genetic variation in reed canarygrass, Phalaris arundinacea L. I. Alkaloid type and concentration. Hereditas 107:235-248.

Ravantti, S. 1980. Ruokohelpi - millainen heinäkasvi. Koetoiminta ja käytäntö 5.2.1980.

Rinne, M., Huhtanen, P., Aura, E., Tirkkonen, L., Nousiainen, J., Hellämäki, M., Mattila, I., Nikander, H., Virkajärvi, P., Isolahti, M., Järvenranta, K. 2002. Nurmen korjuuajan optimoiminen kasvumallien avulla. In: toim. Oiva Niemeläinen, Mari Topi-Hulmi. Nurmirehun kilpailukyvyn parantaminen -tutkimusohjelman päätösseminaari 18.4.2002. Suomen Nurmiyhdistyksen julkaisu 17: p. 29-43.

Salo, R. (toim.). 2000. Biomassan tuottaminen kuidun ja energian raaka-aineeksi. Tutkimuksen loppuraportti, osa I. Ruokohelven jalostus ja viljely. Maatalouden tutkimuskeskus, sarja A 84: 86 s. liitt.1 s.

Sheaffer. C. G., Marten, G. C., Martin, N. P., Miller, D. W., Rabas, D. L. 1990. Reed Canarygrass. Station Bulletin 595-1990. Minnesota Agricultural Experiment Station, University of Minnesota. St. Paul, Minnesota. (AD-SB-5533).

Woods, D. L. \& Clark, K. W. 1971. Genetic control and seasonal variation of some alkaloids in reed canarygrass. Can. J. Plant Sci. 51:323-329. 